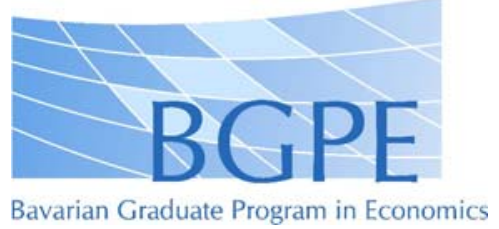

BGPE Discussion Paper

No. 75

\title{
Works Councils and Separations: Voice, Monopoly, and Insurance Effects
}

\author{
Boris Hirsch \\ Thorsten Schank \\ Claus Schnabel
}

June 2009

ISSN 1863-5733

Editor: Prof. Regina T. Riphahn, Ph.D.

Friedrich-Alexander-University Erlangen-Nuremberg

(C) Boris Hirsch, Thorsten Schank, Claus Schnabel 


\title{
Works Councils and Separations: Voice, Monopoly, and Insurance Effects*
}

\author{
Boris Hirsch, Thorsten Schank, Claus Schnabel $^{a}$
}

\begin{abstract}
Using a large linked employer-employee data set for Germany, we find that the existence of a works council is associated with a lower separation rate to employment, in particular for men and workers with low tenure. While works council monopoly effects show up in all specifications, clear voice effects are only visible for low tenured workers. Works councils also reduce separations to non-employment, and this impact is more pronounced for men. Insurance effects only show up for workers with tenure of more than one year. Our results indicate that works councils primarily represent the interests of a specific clientele.
\end{abstract}

Zusammenfassung: Unter Verwendung eines großen kombinierten FirmenBeschäftigten-Datensatzes für Deutschland finden wir, dass die Existenz eines Betriebsrates mit einer geringeren Abgangsrate in (anderweitige) Beschäftigung einhergeht, dies insbesondere bei männlichen Arbeitnehmern und solchen mit geringen Betriebszugehörigkeitsdauern. Während es Anzeichen für Monopoleffekte eines Betriebsrates in allen empirischen Spezifikationen gibt, sind eindeutige Voiceeffekte lediglich für Beschäftige mit geringen Betriebszugehörigkeitsdauern erkennbar. Ein weiteres Ergebnis ist, dass bei Vorhandensein eines Betriebsrates auch die Abgangsrate in Nichtbeschäftigung abnimmt, wobei dieser Effekt abermals bei männlichen Beschäftigten ausgeprägter ist. Diese Versicherungseffekte eines Betriebsrates treten jedoch nur für Arbeitnehmer mit Betriebszugehörigkeitsdauern von über einem Jahr auf. Unsere Ergebnisse deuten darauf hin, dass Betriebsräte in erster Linie die Interessen einer spezifischen Klientel vertreten.

Keywords: works council, separations, collective voice, duration models, Germany

New JEL-Classification: J53, J63

The authors would like to thank Uwe Jirjahn and Joachim Wagner for helpful comments and suggestions.

a Friedrich-Alexander-Universität Erlangen-Nürnberg, Lehrstuhl für Arbeitsmarkt- und Regionalpolitik, Lange Gasse 20, D-90403 Nürnberg, boris.hirsch@wiso.uni-erlangen.de; thorsten.schank@wiso.uni-erlangen.de; claus.schnabel@wiso.uni-erlangen.de 


\section{Introduction}

Labor interest representation at the plant level has been found to affect quits and labor turnover in a number of studies for different countries. In an early test of the exit-voice hypothesis, Freeman (1980) obtains empirical evidence for the U.S. that union workers experience lower quit and separation rates (and more tenure) than non-union workers (see also Freeman and Medoff, 1984; Delery et al., 2000). For the U.K., Addison and Belfield (2004) report that firms with unions have lower quit rates. For Germany, where plant-based works councils rather than industry-level unions act as employees' collective voice at the workplace, most empirical studies find that the presence of a works council reduces separations and labor turnover (see, e.g., Frick and Sadowski, 1995; Frick, 1996; Addison et al., 2001; Dilger, 2002; Frick and Möller, 2003). ${ }^{1}$

Less clear, however, is which kind of separations are reduced by works councils. On the one hand, the presence of a works council can be expected to reduce (voluntary) quits due to collective-voice effects or due to the higher wages paid in firms with works councils. On the other hand, works councils may use their massive consultation and codetermination rights to prevent dismissals and shield employees from unemployment. Such negative effects of works councils on quits and dismissals are found by Frick and Sadowski (1995) and Frick (1996), but a replication study by Kraft (2006) based on the same data set reaches different conclusions. A reduction in voluntary quits is also found by Pfeifer (2007), and Ellguth (2006) obtains some evidence for lower separation rates in establishments with a works council (although dismissals are not reduced in establishments that shed labor). The bulk of other studies usually have not been able to distinguish between voluntary quits by employees and dismissals by employers due to a lack of precise information in the data. What is more, extant studies have not been able to take into account where employees end up after the separation, i.e. whether they move to another firm or become unemployed. We therefore do not know whether works councils just reduce separations or also protect employees from becoming unemployed.

In this study, we use a large-scale linked employer-employee data set for Germany to investigate the effect of works councils on separations. In contrast to previous studies, which have only used establishment data, we are able to take the perspective of employees and pay special attention to the outcome of separations, i.e. whether they result in employment in other firms or in non-employment. We also investigate

$1 \quad$ Notable exceptions are the (small-sample) studies by Kraft (1986), who finds that individual voice but not collective voice via works councils serves to reduce high quit rates, and by Addison, Bellmann, Schnabel, and Wagner (2004), who show that the introduction of a works council does not reduce quit rates (compared to matched pairs of similar firms not introducing a works council). For surveys of the empirical evidence on the economic consequences of works councils, see Addison, Schnabel, and Wagner (2004) or Jirjahn (2006). 
which type of workers benefits most from the presence of a works council, and we improve on previous studies by explicitly taking into account unobserved plant heterogeneity. ${ }^{2}$

The paper proceeds as follows: Section 2 briefly sketches the role and the powers of works councils in Germany and provides some theoretical considerations that are used to derive testable hypotheses on the effects of works councils on separations. Our empirical specification is set up in section 3, while section 4 describes our linked employer-employee data. The results of our empirical investigation are presented and discussed in section 5 , and section 6 concludes.

\section{Institutional Background and Theoretical Considerations}

The German works council is the counterpart of the workplace union in other countries. According to the German Works Constitution Act, works councils are mandatory but not automatic in all establishments exceeding a size threshold of five permanent employees. They are not automatic in that they must be elected (by the entire workforce in the establishment), although just three employees who are at least 18 years old or a trade union represented in the establishment are necessary to start the election procedure. ${ }^{3}$ While works councils are formally independent of unions, in practice the majority of works councilors are union members. The size of the works council is fixed by law and is a function of the establishment's employment level. Works councilors may be full time once certain threshold sizes of employment are reached, and the employer bears the entire cost of the works council apparatus (for more institutional details, see Addison et al., 2001 and Addison, Bellmann, Schnabel, and Wagner, 2004).

Works councils have fairly extensive information, consultation, and codetermination rights prescribed by law. The employer has to provide the works council with both timely and comprehensive information on all matters related to the discharge of its statutory functions. Consultation rights cover such matters as planned structural alterations to the plant, all decisions relating to manpower planning, and individual dismissals. If the employer fails to consult the works council, a dismissal is rendered

$\overline{2}$ In a recent analysis of job duration in Germany, Boockmann and Steffes (2008) also include a works council dummy which is found to reduce separations to employment and unemployment. However, they do not specifically address and disentangle works councils' voice, monopoly, and insurance effects, and they only focus on male employees.

3 Note that in the year 2000, which is at the beginning of our observation period, only about 16 percent of establishments with five employees or more did have a works council, while 53 percent of employees worked in an establishment with a works council (see Addison, Bellmann, Schnabel, and Wagner, 2004). 
null and void. If the employer cannot reach consent with the works council concerning a dismissal, the case usually ends up in labor court. In addition, and in contrast to continental European counterparts of workplace representation, German works councils have codetermination rights on what are termed 'social matters'. These include remuneration arrangements, the commencement and termination of working hours, the regulation of overtime and reduced working hours, and health and safety measures. In all such areas, failure to reach agreement leads to their adjudication through a conciliation board. Works councils can also negotiate social plans, which establish compensation for the dislocation caused by plant closings or partial closings and by major changes in organization.

In contrast to unions, works councils may not call a strike, and they are excluded from reaching agreement with the employer on wages and working conditions that are settled or normally settled by collective agreements between unions and employer associations at industry level (unless the latter explicitly authorize works agreements of this sort). However, their extensive rights of information, consultation, and codetermination on many other issues mean that works councils have a strong influence which can be used for rent-seeking, and unsurprisingly effective wages have been shown to be higher in establishments with works councils (e.g., Addison et al., 2001; Hübler and Jirjahn, 2003).

This brief description of the institutional background makes clear that the German works council is not only a classic vehicle for the expression of collective voice but also has considerable bargaining power which in practice can be applied to all sorts of questions, including wages and dismissals. Against this backdrop, we are now able to analyze the direct and indirect effects of works councils on separations.

According to the exit-voice model of unionism developed by Freeman and Medoff (1984), plant-level unions (and works councils) have two faces or roles. ${ }^{4}$ On the one hand, they represent the preferences of the employees and act as a collective-voice institution that enables employees to safely express their dissatisfaction with certain working conditions instead of quitting the job (or being laid off). If management listens to employees' voice and improves working conditions accordingly, costly quits will be avoided, employee morale will be higher, and labor productivity may rise. On the other hand, unions play a monopoly role: Employees' increased bargaining power is used to push through higher wages, increased employment security, and various other benefits.

Applying this model to the German works council enables us to derive testable hypotheses on the direct and indirect effects of works councils on separations. When formulating these hypotheses we must take into account that our data set (described

$4 \quad$ For extensive (and critical) discussions of this model, see Addison and Belfield (2004) and Dilger (2002). 
in section 4) does not allow us to distinguish between voluntary quits and involuntary dismissals. Instead we are able to distinguish between separations that result in employment in another firm (which may predominantly be voluntary quits) and separations leading to non-employment (most of which may be involuntary).

Starting with separations to employment in other firms, works councils can be expected to reduce this sort of separations through voice and monopoly routes of impact. The collective-voice route is that works councils offer dissatisfied employees who are considering quitting an alternative means of expressing discontent and possibly changing working conditions. In Germany, employees who feel themselves unfairly treated by their supervisors usually contact their works council which will try to solve the problem in discussions or negotiations with management. Moreover, the presence of a works council with extensive legal rights and continuous contact with management can be expected to result in improved labor relations in the establishment, resulting in lower rates of quits and dismissals. The monopoly route of works councils' impact is that quits are likely to be lowered by the improvement in wages and working conditions induced by works councils (and found in almost all empirical studies, see the surveys by Frick and Möller, 2003, and by Addison, Schnabel, and Wagner, 2004). These monopoly effects on wages and working conditions, which are also reflected in lower profits due to works council rent-seeking, must be taken into account in the empirical analysis in order to isolate the collective-voice effect of works councils.

Concerning separations to non-employment, a negative impact might result from the insurance function that works councils have, in particular for those workers who will not easily find a job again. In this perspective, works councils - like other labor market institutions - 'serve an important function of social insurance' (Agell, 2002, p. 108) against labor market risks. In order to prevent (or at least delay) dismissals, they can make use of their specific consultation and consent rights concerning individual dismissals and their codetermination rights concerning mass layoffs and social compensation plans. ${ }^{5}$ They also could transfer their massive bargaining power from other fields in order to convince employers not to lay off employees. ${ }^{6}$ As a result,

5 The Works Constitution Act $(\S \S 102-103)$ stipulates that prior consultation with the works council is a prerequisite for the validity of any dismissal. The works council has one week in which to respond to an ordinary dismissal and three days in case of an extraordinary dismissal. If the works council objects to the dismissal, the employee has a claim to continued employment pending a judicial decision or until a (usually costly) settlement has been reached. For collective dismissals special procedures apply, depending on the size of the establishment and the number of employees affected (see $\S \S 111-113)$. For instance, the works council may contest mass layoffs on the ground that improper criteria were used for the selection of employees to be laid off. For more details on dismissal regulation and the role of works councils, see Frick and Sadowski (1995).

6 However, when analyzing works councils' effects on employment change, Addison and Teixeira (2006) report that works councils do not slow the pace of employment adjustment in Germany. 
the separation rate to non-employment can be expected to be lower in establishments with works councils. ${ }^{7}$

Taken together, these arguments imply two hypotheses on the effects of works councils on separations. First, the existence of a works council can be expected to reduce the separation rate to employment in other firms due to voice and monopoly effects that lower employees' incentives to quit. Second, the separation rate to nonemployment should be lower in plants with works councils due to the insurance function and the legal powers of the works council.

\section{Empirical Specification}

To test the hypotheses laid out in section 2, we will employ methods of competing risks survival analysis, i.e. we will fit competing risks models. ${ }^{8}$ Standard univariate survival analysis models the time spent in a given state before transition to another state. This gives rise to a single hazard rate function, which is the instantaneous probability of leaving the state at some time $t$ conditional on survival up to $t$. Other than univariate survival analysis, competing risks survival analysis allows for the possibility that subjects may exit into more than just one destination state. The term 'competing risks' is used because the subject is confronted with exit probabilities into different, mutually exclusive destination states. By modelling these different destination-specific hazard functions, competing risks models serve as models of multivariate survival analysis.

More concretely, suppose there are $M$ workers (indexed $m=1, \ldots, M$ ) with $N$ employment spells (indexed $i=1, \ldots, N$ ) who work for $J$ firms (indexed $j=1, \ldots, J)$. An employment spell is the period from the beginning until the end of a worker's employment relationship within a particular firm. A worker can exit employment via two possible routes: The worker can either change his or her employer, i.e. he or she separates to employment, (route $e$ ) or can change to nonemployment (route $n$ ). Let $T^{r}$ denote the latent spell duration for exit via route $r$ with $r=e, n$. $T^{r}$ thus gives the spell duration if there were no other routes than $r$, which may cause the employment spell to end. $T^{r}$ is latent because the duration of

$7 \quad$ It could be argued that two other impacts of works council presence on economic performance found in most empirical studies (see the survey by Addison, Schnabel, and Wagner, 2004) may play an indirect role for separations. First, works council rent-seeking usually results in higher labor cost and lower company profits, which in turn may lead to higher layoff rates. Second, the presence of a works council is often associated with higher productivity in the establishment, which in turn could either reduce the need to lay off the more costly workers or could increase the number of layoffs if productivity increases are labor-saving. However, these level-effects should only show up after the introduction of a works council (which we are not able to investigate).

$8 \quad$ For details about competing risks models we refer to Cameron and Trivedi (2005, ch. 19) and Jenkins (2005, ch. 9). 
an employment spell is either censored, i.e. no exit takes place during observation, or ends with a separation to employment or non-employment. Hence, the observed duration for the $i$-th employment spell $T_{i}$ is given by

$$
T_{i}=\min \left\{T_{i}^{e}, T_{i}^{n}, T_{i}^{c}\right\}
$$

where $T_{i}^{c}$ refers to the duration of a censored employment spell without any exit during the period of observation.

Let $s_{i}^{e}(t)$ denote the latent instantaneous separation rate to employment at time $t$ and $s_{i}^{n}(t)$ the latent instantaneous separation rate to non-employment at time $t$, where $t$ corresponds to the time elapsed since the beginning of the spell (that is the worker's tenure). Let further $s_{i}(t)$ denote the overall instantaneous separation rate at time $t$. Assuming (conditional) independence in competing risks, i.e. latent failure times and thus route-specific hazard rates are independent, we arrive at

$$
s_{i}(t)=s_{i}^{e}(t)+s_{i}^{n}(t) .
$$

The overall separation rate is then the sum of the two route-specific separation rates. Under the independence in competing risks assumption, the estimation of the competing risks model becomes straightforward: We just have to estimate two separate hazard rate models for the instantaneous separation rates to employment and non-employment, where exits via the other route are considered as censored spells.

In a next step, we have to model the route-specific separation rates $s_{i}^{e}$ and $s_{i}^{n}$. Let $x_{i}^{r}(t)=\left(x_{i 1}^{r}(t), \ldots, x_{i k}^{r}(t)\right)$ denote a vector of $k$ time-varying covariates observed for employment spell $i$ at time $t$ with $r=e, n$. Next, let $\beta^{r}=\left(\beta_{1}^{r}, \ldots, \beta_{k}^{r}\right)^{\prime}$ denote a vector of $k$ coefficients which are the same for all spells $i$ and constant over time. Analogously, $z_{j(i)}^{r}(t)=\left(z_{j(i) 1}^{r}(t), \ldots, z_{j(i) l}^{r}(t)\right)$ is a vector of $l$ time-varying covariates observed for firm $j(i)$ at time $t$, for which the worker with spell $i$ is working, while $\gamma^{r}=\left(\gamma_{1}^{r}, \ldots, \gamma_{l}^{r}\right)^{\prime}$ denotes the corresponding vector of $l$ coefficients. Finally, let $v_{j(i)}^{r}$ denote a firm-specific time-invariant constant. We model the instantaneous separation rate via route $r$ of the $i$-th spell at time $t$ conditional on $x_{i}^{r}(t), z_{j(i)}^{r}(t)$, and $v_{j(i)}^{r}$ as

$$
s_{i}^{r}\left(t \mid x_{i}^{r}(t), z_{j(i)}^{r}(t), v_{j(i)}^{r}\right)=v_{j(i)}^{r} s_{0}^{r}(t) \exp \left(x_{i}^{r}(t) \beta^{r}+z_{j(i)}^{r}(t) \gamma^{r}\right) .
$$

Equation (3) therefore defines conditional proportional hazard functions with baseline hazard $s_{0}^{r}(t)$ and unobserved heterogeneity at the level of the firm $v_{j(i)}^{r}$, i.e. two mixed proportional hazard models with time-varying covariates. ${ }^{9}$

$\overline{9}$ By analogy, unobserved heterogeneity at the level of the worker could be taken into account 
Specifying $s_{0}^{r}(t)$ as a step function in the worker's tenure, we arrive at a piecewiseconstant exponential model. Moreover, we assume that $v_{j(i)}^{r}$ follows a Gamma distribution with mean one and finite variance, i.e. $\mathrm{E}\left[v_{j(i)}^{r}\right]=1$ and $\operatorname{Var}\left[v_{j(i)}^{r}\right]<\infty$, as put forward by Abbring and van den Berg (2007). Therefore, we get two piecewiseconstant exponential models with shared gamma frailties, which can be thought of as gamma-distributed random effects reflecting unobserved heterogeneity at the level of the firm. As stated above, the estimation of the competing risks model is then achieved by separate estimation of these two models.

If $z_{j(i)}^{r}(t)$ includes a works council dummy $W C_{j(i)}(t)$, which is one if spell $i$ is an employment spell in a firm with a works council at time $t$ and zero otherwise, then

$$
\frac{\partial \ln s_{i}^{r}\left(t \mid x_{i}^{r}(t), z_{j(i)}^{r}(t), v_{j(i)}^{r}\right)}{\partial W C_{j(i)}(t)}=\beta_{W C}^{r}
$$

where $\beta_{W C}^{r}$ denotes the route-specific coefficient of the works council dummy. ${ }^{10}$ Hence, $\exp \beta_{W C}^{r}-1$ gives the ceteris paribus percentage change in the instantaneous route-specific separation rate through a works council.

\section{Data}

The data set used in subsequent empirical analyses is the German LIAB, i.e. the Linked Employer-Employee Data Set of the Institute for Employment Research (Institut für Arbeitsmarkt- und Berufsforschung, IAB) of the German Federal Employment Agency (Bundesagentur für Arbeit). The LIAB is created by linking the process-produced person-specific data of the IAB with the IAB Establishment Panel (cf. Alda et al., 2005). Using the LIAB we are therefore able to control both for personal and establishment characteristics.

The employee history used for constructing the LIAB is based on the integrated notification procedure for the health, pension, and unemployment insurances. ${ }^{11}$ This procedure requires all employers to report all information of their employees if covered by the social security system, where misreporting is legally sanctioned. Notifications are compulsory both at the beginning and the end of employment. Additionally, an annual report must be made for each employee employed on the 31st

by including a term $v_{m(i)}^{r}$ multiplicatively. However, in our empirical analysis we only have one spell per worker (see footnote 14). Hence, including gamma frailties to allow for unobserved worker heterogeneity proved to be insignificant and its inclusion did not change the parameter estimates of the other variables, so that we neglect the respective mixed proportional hazards in our further analysis. For details about mixed proportional hazard models, see Cameron and Trivedi (2005, chs. 17/18), Jenkins (2005), and van den Berg (2001).

10 Note that unlike the general expression in equation (4), in our empirical analysis the works council dummy is a non-time-varying variable due to the construction of the data set.

11 Details are given by Alda et al. (2005) and Bender et al. (2000). 
of December of the year. As a consequence, only those workers, salaried employees, and trainees who are covered by social security are included. Thus, among others, civil servants, self-employed, those in marginal employment, students enrolled in higher education, and family workers are not included. All in all, approximately 80 percent of all people employed in western Germany are part of the employee history.

The data include, among others things, information for every employee on daily gross wage, censored at the social security contribution ceiling, on the employee's occupation and occupational status, on industry, and on the start and end of each employee notification. Furthermore, individual characteristics, such as age, schooling, and nationality are contained. Finally, an establishment number is included which is used to link the employee history and the IAB Establishment Panel.

The employer side of our data set is given by the IAB Establishment Panel, a random sample of establishments (not firms) from the comprehensive Employment Statistics drawn according to the principle of optimal stratification. ${ }^{12}$ Strata are defined over plant sizes and industries, where all in all ten plant sizes and 16 industries are considered. Since the survey is based on the Employment Statistics aggregated via the establishment number as of the 30th of June of a year, it only includes establishments which employ at least one employee covered by social security. Every year since 1993 (1996) the IAB Establishment Panel has surveyed the same establishments from all industries in western (eastern) Germany. Response rates of units which have been interviewed repeatedly exceed 80 percent. The IAB Establishment Panel is created to serve the needs of the Federal Employment Agency, so that the focus on employment-related topics is predominant. Questions deal, among other things, with the number of employees, the working week for full-time workers, coverage by collective agreements, the existence of a works council, the establishment's performance and export share, and the technological status of the plant.

Linking both the IAB Establishment Panel and the employee history through the establishment number gives the LIAB. ${ }^{13}$ We will use version 2 of the LIAB longitudinal model, which is based on a balanced panel of establishments participating in the IAB Establishment Panel in each year between 2000 and 2002 and provides information on all workers which have been employed by any of these establishments for at least one day. The information of whether or not a plant has a works council (which is our main variable of interest in explaining the separation probabilities) refers to the 30th of June of the respective years (2000, 2001, and 2002). We select those workers who are employed by any of the establishments at the 30th

12 Details about the IAB Establishment Panel are given by Kölling (2000).

13 Details about the different LIAB models and their versions are given by Alda (2005). 
of June 2000 and follow them until the 30th of June 2002. ${ }^{14}$ We do not investigate the time periods before and afterwards to ensure that we have complete information on the works council regime. ${ }^{15}$ We have argued above that a works council may reduce dismissals to non-employment due to its legal powers. However, Addison, Bellmann, and Kölling (2004) and Andrews et al. (2007) find a positive association between works council presence and plant closings. To rule out this second effect we have excluded those plants with considerable downsizing and closings since the determinants of separation in those plants are quite distinct (so that one should not pool all observations into one regression). More precisely, we excluded plants with a workforce of at least ten employees that experienced an employment reduction by at least 25 percent between 2000 and 2002.

For all workers we have accurate information on their employment spells. Workers who are still employed by the same establishment at the 30th of June 2002 are treated as censored. For those who leave their establishments between 30th of June 2000 and 30th of June 2002, we know whether they move to another plant or whether they move to non-employment. Therefore, we are able to construct the separation rates discussed in section 3, viz. the separation rate to employment and the separation rate to non-employment, where employment refers to employment at another establishment. ${ }^{16}$ Separations into non-employment end either in unemployment or are not recorded in the data any more ('unknown'). The latter either implies that the person has changed to non-employment without receiving benefits from the unemployment office or that the person has become, for instance, a self-employed not included in the employee history. While our data set does not enable us to disaggregate this category of unknown destination, information from other data sets suggests that the majority of employees in this category have moved to non-employment. ${ }^{17}$ Therefore, we have pooled the separations into unemployment and the separations into 'unknown' to separations into non-employment. We have not modelled them separately because the assumption of independent hazards of separating into unemployment and of separating into the 'unknown' group would clearly be erroneous.

\footnotetext{
14 If a worker moves to another establishment, then the duration of his new employment relationship is not considered. Hence, our data set consists of one spell per worker.

15 By a similar argument, we have dropped those establishments which have changed their works council regime between 2000 and 2002, since we do not know when the change actually takes place. This reduced our regression sample from 2,667 to 2,493 plants.

16 As mentioned above, we do not observe whether a separation is initiated by the employer (a dismissal) or the employee (a quit). However, we expect that quits are more likely if the worker separates to employment, while the probability of a dismissal is higher if a separation to non-employment occurs.

17 See, for example, Bartelheimer and Wieck (2005) for a transition matrix between employment and non-employment, based on the German Socio-Economic Panel, which allows stratification of the 'unknown' into detailed categories.
} 
We restrict our analysis to western Germany (since the eastern Germany labor market is still in a special transformation process) and to full-time employees ${ }^{18}$. This leaves us - after dropping establishments (and their employees) with missing values of the covariates in any of the years - with information on a stock of 101,759 employees working for 2,493 establishments at the 30th of June 2000, 1,193 of which have a works council. Table 1 reports that 9,147 employees leave their establishments to join another company, while 5,714 workers exit to nonemployment. The remaining 86,898 workers are employed by the same establishment until the 30th of June 2002. It turns out that both separation rates are lower if a works council exists. Therefore, the descriptive statistics confirm the theoretical expectations from section 2. The existence of a works council reduces the separation rate for all reported subgroups (male vs. female, workers with tenure of no more than one year vs. workers with more tenure). Furthermore, it can be seen that the reduction in the exit probabilities associated with the existence of a works council is larger for men than for women. Finally, works councils have a greater impact on the raw hazards for separations to non-employment than for separations to employment.

Of course, these relationships may change once we take other covariates into account. For example, the reduction in separation rates associated with the existence of a works council may simply reflect the fact that works councils are more often found in large establishments which have lower separation rates. Due to the inclusion of establishment data, we are able to control as well for person-specific characteristics as for characteristics of the establishment the employee is working for. Therefore, the labor market's demand and supply sides can be taken into consideration. The sample means of the works council dummy and other explanatory variables are displayed in the appendix table.

A shortcoming of the LIAB is that daily gross wages, which are one of our control variables, are censored at the social security contribution ceiling, viz. €143.95 in $2000, € 146.02$ in 2001 , and $€ 147.95$ in 2002 . This affects about 10 percent of the observations in our sample. Obviously, using wage data without any correction would give biased estimates. We deal with this problem by applying single imputation, i.e. imputing all censored wages with estimated wages. Assuming that daily gross wages have a log-normal distribution, which seems to be a plausible approximation, first a Tobit model is estimated, where the dependent variable is log daily gross wage and the independent variables are those included in further analyses. Then

18 Since there is no detailed information on the number of hours worked, we exclude employees working part-time (at any time in the observation period). Moreover, apprentices and a small number of employees experiencing recalls are excluded. In addition, we keep only individuals which were on the 1st of January 2000 between 16 and 55 years old, where the upper bound should ensure that the transitions into non-employment are not due to (early) retirement. Finally, notifications which start and end at the same day and benefit notifications which correspond to employment notifications at the same time are deleted. 
Table 1: Worker separations for different subgroups (percentages in brackets)

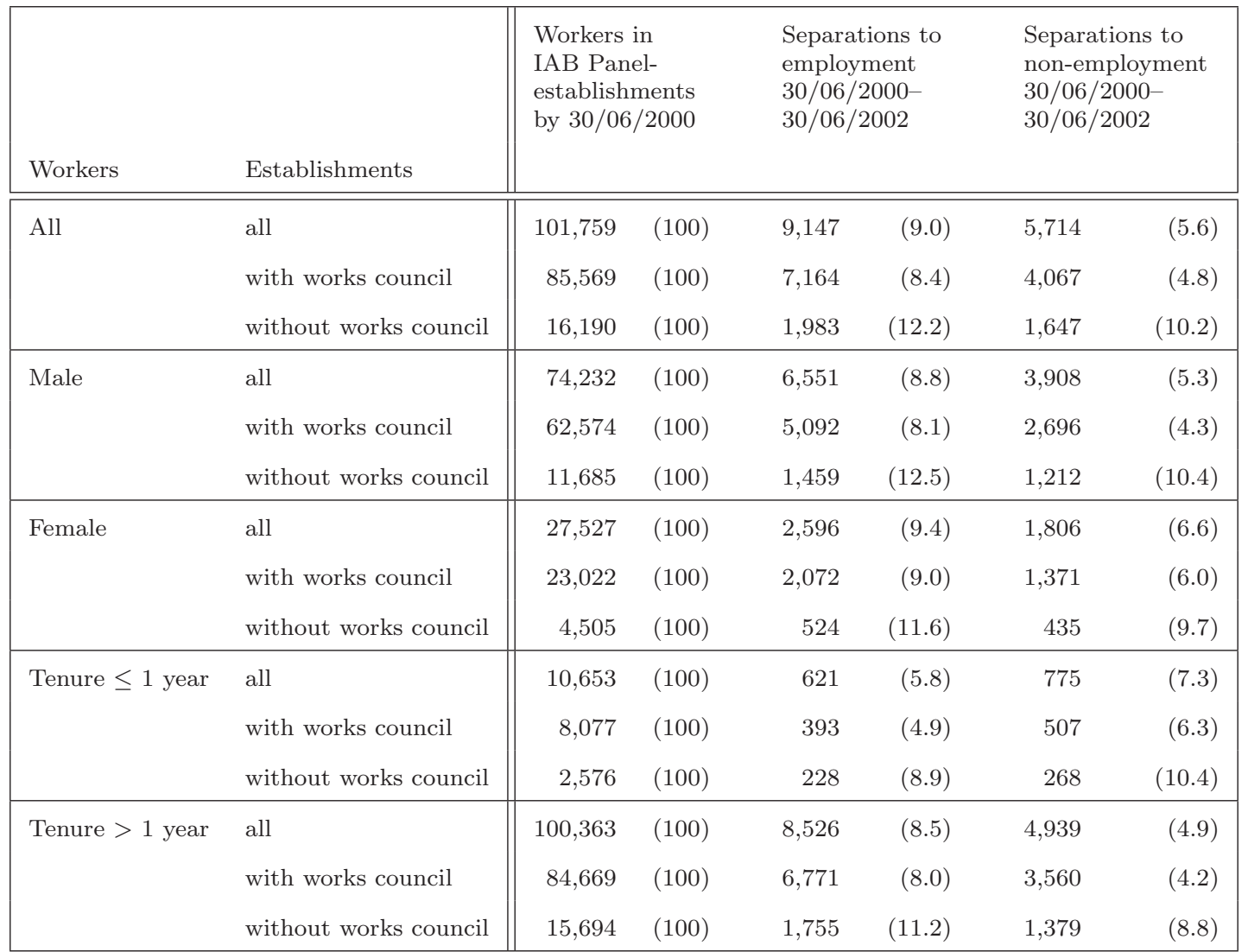

Notes:

The sum of workers with not more than one year of tenure and of workers with more than one year of tenure $(111,016)$ is larger than the total number of workers $(101,759)$ since 9,257 workers switch between both categories during the observation period.

for every censored observation a random value is drawn from a normal distribution left-truncated at the social security contribution ceiling (with predicted log wage as mean, and standard deviation as estimated from the Tobit model). ${ }^{19}$

\section{Econometric Analysis}

In this section, we turn to our multivariate analyses. We fit independent competing risk models, where the instantaneous separation rates to employment and nonemployment are modelled as piecewise-constant exponential models both with and without shared gamma frailties at the level of the establishment. The baseline hazard is modelled as a step function in the worker's tenure. ${ }^{20}$ Our main focus

\footnotetext{
19 For details on single imputation in the case of censored wages see Gartner (2005).

20 Tenure categories are 0-30, 31-60, 61-90, 91-120, 121-150, 151-180, 181-210, 211-240, 241270, 271-300, 301-330, 331-360, 361-720, 721-1080, 1081-1440, 1441-1800, 1801-2160, 21612520, 2521-2800, 2881-3240, 3241-3600, 3601-5400, 5401-7200, and more than 7200 days of employment, respectively.
} 
is on the effect of the works council dummy on separations. All regressions also include a number of personal and establishment characteristics as control variables. Personal characteristics are represented by a male and a non-German dummy, nine age dummies, six education dummies, and ten occupation dummies. Establishment characteristics include five establishment size dummies, two dummies indicating whether the establishment is covered by collective agreements, a dummy indicating good technological status, the proportions of female as well as qualified workers, and ten sectoral dummies. Finally, we add three year dummies. For a discussion of the expected impact of these control variables on the respective separation rates we refer to Hirsch et al. (2008).

As argued above and confirmed descriptively, the existence of a works council is likely to reduce the separation rate to employment due to voice and monopoly effects. In the first and the third column of table 2 this is indeed found. The coefficient of the works council dummy is negative and statistically significant at the 5 percent level. The effect is also significant from an economic point of view because estimated coefficients of -0.136 without and -0.139 with establishment frailties indicate that the existence of a works council is associated with a ceteris paribus decline in the separation rate to employment by 12.7 and 13.0 percent, respectively. Put differently, the separation rate to employment in plants without a works council, which is 12.2 percent in table 1 , would be (evaluated at the sample average) about 1.5 percentage points lower if a works council existed.

However, these estimates (which are consistent with Boockmann and Steffes, 2008), mix the monopoly and the voice effect. To disentangle these two effects, we include in a next step the worker's log daily gross wage (similar to Freeman, 1980) and a dummy indicating whether the responding manager rated the establishment's profit situation as bad (i.e. 4 or 5 on a descending five-point index). These control variables should capture the indirect impact of a works council on workers' separation rate via its impact on workers' wages and establishments' profitability due to the monopoly effect. Consequently, the estimated coefficient of the works council dummy should now be lower. This is clearly confirmed by the estimates presented in columns two and four. The two additional control variables have the expected effects: The probability of separation to employment correlates negatively with the level of wages and is substantially higher in plants with bad profitability. Correspondingly, the size of the estimated coefficient of the works council dummy is reduced markedly, which reflects the works council's monopoly effect. ${ }^{21}$ While still negative, the coefficient of

21 It might be argued that a works council's wage effect is simply due to higher productivity of firms with works councils, in which case higher wages do not necessarily imply a monopoly effect. However, when including labor productivity as an additional regressor, its coefficient turned out to be small and insignificant, while the parameter estimates of the works council dummy and the wage variable were hardly affected. Therefore, we conclude that our argument 
Table 2: Determinants of workers' instantaneous separation rate to employment

\begin{tabular}{|c|c|c|c|c|}
\hline \multirow{2}{*}{$\begin{array}{l}\text { Explanatory variables } \\
\text { Works council (dummy) }\end{array}$} & \multicolumn{2}{|c|}{ without establishment-frailties } & \multicolumn{2}{|c|}{ with establishment-frailties } \\
\hline & $-0.136(0.058)$ & $-0.106(0.057)$ & $-0.139(0.054)$ & $-0.080(0.054)$ \\
\hline Log daily gross wage (in €) & & $-0.508(0.082)$ & & $-0.597(0.047)$ \\
\hline Male (dummy) & $0.060(0.035)$ & $0.166(0.037)$ & $0.054(0.028)$ & $0.172(0.030)$ \\
\hline Non-German (dummy) & $-0.217(0.065)$ & $-0.219(0.064)$ & $-0.258(0.051)$ & $-0.266(0.051)$ \\
\hline Age under 21 years (ref. group) & - & - & $\overline{-}$ & \\
\hline Age $21-25$ years (dummy) & $-0.227(0.154)$ & $-0.179(0.153)$ & $-0.196(0.148)$ & $-0.148(0.149)$ \\
\hline Age $26-30$ years (dummy) & $-0.326(0.155)$ & $-0.236(0.153)$ & $-0.271(0.147)$ & $-0.177(0.147)$ \\
\hline Age $31-35$ years (dummy) & $-0.496(0.154)$ & $-0.372(0.153)$ & $-0.448(0.147)$ & $-0.315(0.147)$ \\
\hline Age $36-40$ years (dummy) & $-0.717(0.156)$ & $-0.577(0.154)$ & $-0.678(0.147)$ & $-0.526(0.148)$ \\
\hline Age $41-45$ years (dummy) & $-0.949(0.157)$ & $-0.802(0.155)$ & $-0.912(0.148)$ & $-0.751(0.149)$ \\
\hline Age $46-50$ years (dummy) & $-1.138(0.160)$ & $-0.988(0.157)$ & $-1.108(0.150)$ & $-0.943(0.150)$ \\
\hline Age $51-55$ years (dummy) & $-1.237(0.167)$ & $-1.086(0.165)$ & $-1.213(0.153)$ & $-1.048(0.153)$ \\
\hline Age $56-58$ years (dummy) & $-1.139(0.204)$ & $-0.989(0.204)$ & $-1.118(0.190)$ & $-0.957(0.191)$ \\
\hline No apprenticeship, no Abitur (ref. group) & - & - & - & - \\
\hline Apprenticeship, no Abitur (dummy) & $-0.003(0.059)$ & $0.056(0.057)$ & $0.050(0.041)$ & $0.116(0.041)$ \\
\hline No apprenticeship, with Abitur (dummy) & $0.206(0.126)$ & $0.276(0.126)$ & $0.290(0.118)$ & $0.351(0.118)$ \\
\hline Apprenticeship and Abitur (dummy) & $0.160(0.072)$ & $0.261(0.070)$ & $0.184(0.060)$ & $0.297(0.061)$ \\
\hline Technical college degree (dummy) & $0.288(0.078)$ & $0.445(0.078)$ & $0.328(0.063)$ & $0.505(0.065)$ \\
\hline University degree (dummy) & $0.392(0.078)$ & $0.604(0.081)$ & $0.453(0.061)$ & $0.669(0.063)$ \\
\hline Basic manual occupation (ref. group) & - & - & - & - \\
\hline Qualified manual occupation (dummy) & $0.240(0.066)$ & $0.267(0.065)$ & $0.172(0.043)$ & $0.209(0.043)$ \\
\hline Engineers and technicians (dummy) & $0.349(0.064)$ & $0.483(0.068)$ & $0.364(0.050)$ & $0.525(0.051)$ \\
\hline Basic service occupation (dummy) & $0.123(0.085)$ & $0.122(0.083)$ & $0.162(0.055)$ & $0.170(0.055)$ \\
\hline Qualified service occupation (dummy) & $0.383(0.120)$ & $0.446(0.121)$ & $0.273(0.096)$ & $0.359(0.097)$ \\
\hline Semi-professional (dummy) & $0.389(0.095)$ & $0.527(0.099)$ & $0.405(0.073)$ & $0.563(0.074)$ \\
\hline Professional (dummy) & $0.690(0.111)$ & $0.867(0.116)$ & $0.660(0.088)$ & $0.885(0.089)$ \\
\hline Basic business occupation (dummy) & $0.603(0.080)$ & $0.690(0.083)$ & $0.510(0.061)$ & $0.614(0.061)$ \\
\hline Qualified business occupation (dummy) & $0.432(0.066)$ & $0.552(0.068)$ & $0.359(0.046)$ & $0.493(0.047)$ \\
\hline Manager (dummy) & $0.527(0.082)$ & $0.750(0.094)$ & $0.544(0.071)$ & $0.810(0.074)$ \\
\hline Number of employees $\leqslant 20$ (ref. group) & - & - & - & - \\
\hline Number of employees 21-100 (dummy) & $-0.247(0.081)$ & $-0.198(0.082)$ & $-0.296(0.065)$ & $-0.244(0.065)$ \\
\hline Number of employees 101-199 (dummy) & $-0.224(0.091)$ & $-0.149(0.093)$ & $-0.270(0.074)$ & $-0.203(0.075)$ \\
\hline Number of employees 200-299 (dummy) & $-0.200(0.099)$ & $-0.116(0.098)$ & $-0.319(0.080)$ & $-0.241(0.080)$ \\
\hline Number of employees $\geqslant 300$ (dummy) & $-0.367(0.105)$ & $-0.279(0.106)$ & $-0.360(0.080)$ & $-0.285(0.081)$ \\
\hline Coll. agreement at sect. level (dummy) & $-0.046(0.052)$ & $-0.031(0.051)$ & $-0.038(0.045)$ & $-0.020(0.045)$ \\
\hline Coll. agreement at firm level (dummy) & $0.096(0.092)$ & $0.106(0.091)$ & $0.112(0.061)$ & $0.119(0.061)$ \\
\hline Proportion of female workers & $-0.030(0.120)$ & $-0.116(0.119)$ & $-0.093(0.088)$ & $-0.177(0.088)$ \\
\hline Proportion of qualified workers & $-0.119(0.110)$ & $-0.075(0.112)$ & $-0.222(0.067)$ & $-0.166(0.067)$ \\
\hline New production technology (dummy) & $-0.136(0.066)$ & $-0.108(0.064)$ & $-0.090(0.032)$ & $-0.075(0.032)$ \\
\hline Bad economic profitability (dummy) & & $0.214(0.058)$ & & $0.153(0.035)$ \\
\hline Ten sectoral dummies & $p=0.012$ & $p=0.015$ & $p<0.001$ & $p<0.001$ \\
\hline Year 2000 (ref. group) & - & - & - & - \\
\hline Year 2001 (dummy) & $-0.321(0.044)$ & $-0.319(0.044)$ & $-0.307(0.024)$ & $-0.297(0.024)$ \\
\hline Year 2002 (dummy) & $-0.696(0.076)$ & $-0.701(0.076)$ & $-0.668(0.034)$ & $-0.661(0.034)$ \\
\hline Frailty variance $(\hat{\vartheta})$ & & & $0.352(0.022)$ & $0.352(0.022)$ \\
\hline Observations & 471,874 & 471,874 & 471,874 & 471,874 \\
\hline Workers & 101,759 & 101,759 & 101,759 & 101,759 \\
\hline Transitions & 9,147 & 9,147 & 9,147 & 9,147 \\
\hline Log likelihood & $-20,625.908$ & $-20,517.907$ & $-19,800.204$ & $-19,707.980$ \\
\hline McFadden- $R^{2}$ & 0.113 & 0.118 & 0.149 & 0.153 \\
\hline
\end{tabular}

Notes:

The data set used is version 2 of the LIAB longitudinal model. Robust standard errors (adjusted for intraestablishment correlations in the non-frailty models) are given in parentheses. The dependent variable is a dummy variable taking the value one if the individual changes from an IAB Panel-establishment to another establishment and zero otherwise. Piecewise constant exponential models are fitted with and without shared gamma frailties, where the baseline hazard is a step function in the worker's tenure. Tenure categories are given as 0-30, 31-60, 61-90, 91-120, 121-150, 151-180, 181-210, 211-240, 241-270, 271-300, 301-330, 331-360, 361-720, 721-1080, 1081-1440, 1441-1800, 1801-2160, 2161-2520, 2521-2800, 2881-3240, 3241-3600, 3601-5400, 5401-7200, and more than 7200 days of employment, respectively. 
the works council dummy does not differ statistically from zero at the 5 percent level anymore, so that there is only weak evidence for a voice effect in the full sample. ${ }^{22}$

The second hypothesis we are interested in is whether the existence of a works council reduces the separation rate to non-employment, as reported in our descriptive analysis. This is likely to be the case due to works councils' insurance function, which should protect workers against dismissals and thus decrease their separation rate to non-employment, ceteris paribus. As shows up in the first and the third column of table 3 , the existence of a works council has indeed a large and statistically significant negative effect (at the 1 percent level) on the separation rate to non-employment. Estimated coefficients of -0.464 without and -0.456 with establishment frailties indicate that the existence of a works council is associated with a ceteris paribus decrease of the separation rate to non-employment by 37.1 and 36.6 percent, respectively.

This effect, however, is likely to overestimate the impact of the works council's insurance function. Separations to non-employment include both voluntary and involuntary transitions, and voluntary transitions can be expected to be lower if wages are higher. Since works councils usually increase workers' wages, the volume of voluntary quits to non-employment is likely to depend negatively on the existence of a works council. Thus, there should be a negative effect even if the works council were not to exercise its insurance function at all. By controlling for the worker's daily gross wage and the establishment's profitability status, we expect to capture this indirect effect of a works council on the workers' separation rate to non-employment. Hence, the estimated coefficient of the works council dummy should be lower when these additional regressors are included. The estimates in columns two and four are in line with these considerations. The magnitude of the estimated coefficient of the works council dummy is reduced by roughly one third, but it remains large and statistically significant at the 1 percent level. Separation rates are 26.7 and 23.7 percent lower, respectively, if workers are employed in an establishment with a works council.

In a next step, it seems interesting to look whether there are differences in the impact of a works council for different subgroups of workers. Do separation rates differ because works councils represent the interests of a specific clientele and try to improve the working conditions primarily of their median voters? In particular, are there gender differences and differences according to tenure, which showed up in the descriptive analysis in section 4 ?

remains valid that the wage variable mainly reflects a monopoly effect.

22 Since there was a reform of the Works Constitution Act in mid-2001, which slightly increased the powers of the works council, we investigated whether works council impact was different in 2002 by including a corresponding interaction term. This robustness check (the results of which are available upon request) did not change our insights. 
Table 3: Determinants of workers' instantaneous separation rate to non-employment

\begin{tabular}{|c|c|c|c|c|}
\hline \multirow{2}{*}{$\begin{array}{l}\text { Explanatory variables } \\
\text { Works council (dummy) }\end{array}$} & \multicolumn{2}{|c|}{ without establishment-frailties } & \multicolumn{2}{|c|}{ with establishment-frailties } \\
\hline & $-0.464(0.104)$ & $=0.311(0.094)$ & $=0.456(0.063)$ & 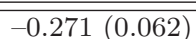 \\
\hline Log daily gross wage (in $€$ ) & & $-1.547(0.083)$ & & $-1.501(0.052)$ \\
\hline Male (dummy) & $-0.233(0.042)$ & $0.111(0.047)$ & $-0.237(0.035)$ & $0.075(0.037)$ \\
\hline Non-German (dummy) & $0.367(0.105)$ & $0.377(0.092)$ & $0.365(0.046)$ & $0.341(0.046)$ \\
\hline Age under 21 years (ref. group) & - & - & - & - \\
\hline Age $21-25$ years (dummy) & $-0.493(0.123)$ & $-0.278(0.139)$ & $-0.424(0.123)$ & $-0.164(0.126)$ \\
\hline Age $26-30$ years (dummy) & $-0.606(0.125)$ & $-0.289(0.145)$ & $-0.544(0.121)$ & $-0.187(0.124)$ \\
\hline Age $31-35$ years (dummy) & $-0.718(0.124)$ & $-0.330(0.144)$ & $-0.636(0.121)$ & $-0.206(0.124)$ \\
\hline Age $36-40$ years (dummy) & $-0.912(0.126)$ & $-0.487(0.147)$ & $-0.827(0.122)$ & $-0.362(0.125)$ \\
\hline Age $41-45$ years (dummy) & $-1.061(0.128)$ & $-0.621(0.147)$ & $-0.961(0.124)$ & $-0.481(0.127)$ \\
\hline Age $46-50$ years (dummy) & $-1.039(0.132)$ & $-0.596(0.152)$ & $-0.945(0.125)$ & $-0.471(0.127)$ \\
\hline Age $51-55$ years (dummy) & $-0.825(0.136)$ & $-0.385(0.153)$ & $-0.717(0.127)$ & $-0.241(0.130)$ \\
\hline Age $56-58$ years (dummy) & $-0.145(0.177)$ & $0.288(0.191)$ & $-0.024(0.151)$ & $0.425(0.154)$ \\
\hline No apprenticeship, no Abitur (ref. group) & $\overline{-}$ & - & - & - \\
\hline Apprenticeship, no Abitur (dummy) & $-0.321(0.060)$ & $-0.152(0.054)$ & $-0.297(0.043)$ & $-0.134(0.043)$ \\
\hline No apprenticeship, with Abitur (dummy) & $0.222(0.130)$ & $0.280(0.153)$ & $0.212(0.133)$ & $0.266(0.134)$ \\
\hline Apprenticeship and Abitur (dummy) & $-0.256(0.088)$ & $0.045(0.086)$ & $-0.251(0.078)$ & $0.046(0.079)$ \\
\hline Technical college degree (dummy) & $-0.243(0.103)$ & $0.219(0.098)$ & $-0.245(0.087)$ & $0.190(0.088)$ \\
\hline University degree (dummy) & $0.067(0.099)$ & $0.693(0.091)$ & $0.048(0.076)$ & $0.616(0.078)$ \\
\hline Basic manual occupation (ref. group) & - & - & - & - \\
\hline Qualified manual occupation (dummy) & $-0.072(0.097)$ & $-0.001(0.090)$ & $-0.153(0.050)$ & $-0.084(0.050)$ \\
\hline Engineers and technicians (dummy) & $-0.307(0.085)$ & $0.097(0.083)$ & $-0.296(0.068)$ & $0.097(0.069)$ \\
\hline Basic service occupation (dummy) & $-0.182(0.105)$ & $-0.188(0.096)$ & $-0.129(0.060)$ & $-0.111(0.060)$ \\
\hline Qualified service occupation (dummy) & $-0.258(0.156)$ & $-0.054(0.155)$ & $-0.261(0.121)$ & $-0.057(0.122)$ \\
\hline Semi-professional (dummy) & $-0.167(0.124)$ & $0.251(0.117)$ & $-0.218(0.087)$ & $0.189(0.088)$ \\
\hline Professional (dummy) & $0.405(0.136)$ & $0.913(0.126)$ & $0.420(0.106)$ & $0.930(0.105)$ \\
\hline Basic business occupation (dummy) & $-0.079(0.094)$ & $0.118(0.096)$ & $-0.092(0.077)$ & $0.113(0.077)$ \\
\hline Qualified business occupation (dummy) & $-0.212(0.078)$ & $0.135(0.073)$ & $-0.201(0.056)$ & $0.103(0.057)$ \\
\hline Manager (dummy) & $0.003(0.117)$ & $0.667(0.114)$ & $0.090(0.092)$ & $0.733(0.095)$ \\
\hline Number of employees $\leqslant 20$ (ref. group) & - & - & - & - \\
\hline Number of employees $21-100$ (dummy) & $-0.049(0.080)$ & $0.113(0.083)$ & $-0.109(0.077)$ & $0.021(0.076)$ \\
\hline Number of employees 101-199 (dummy) & $-0.074(0.113)$ & $0.132(0.112)$ & $-0.143(0.089)$ & $0.024(0.088)$ \\
\hline Number of employees 200-299 (dummy) & $-0.158(0.116)$ & $0.088(0.117)$ & $-0.306(0.096)$ & $-0.098(0.095)$ \\
\hline Number of employees $\geqslant 300$ (dummy) & $-0.216(0.134)$ & $0.063(0.134)$ & $-0.272(0.096)$ & $-0.059(0.095)$ \\
\hline Coll. agreement at sect. level (dummy) & $0.046(0.074)$ & $0.098(0.068)$ & $0.039(0.053)$ & $0.075(0.053)$ \\
\hline Coll. agreement at firm level (dummy) & $-0.003(0.099)$ & $0.037(0.092)$ & $0.014(0.076)$ & $0.039(0.075)$ \\
\hline Proportion of female workers & $-0.192(0.156)$ & $-0.417(0.138)$ & $-0.198(0.102)$ & $-0.380(0.100)$ \\
\hline Proportion of qualified workers & $-0.458(0.138)$ & $-0.256(0.129)$ & $-0.300(0.079)$ & $-0.126(0.078)$ \\
\hline New production technology (dummy) & $-0.102(0.059)$ & $-0.046(0.056)$ & $-0.108(0.039)$ & $-0.078(0.038)$ \\
\hline Bad economic profitability (dummy) & & $0.279(0.059)$ & & $0.257(0.042)$ \\
\hline Ten sectoral dummies & $p<0.001$ & $p<0.001$ & $p<0.001$ & $p<0.001$ \\
\hline Year 2000 (ref. group) & - & - & - & - \\
\hline Year 2001 (dummy) & $-0.242(0.044)$ & $-0.239(0.044)$ & $-0.241(0.032)$ & $-0.233(0.032)$ \\
\hline Year 2002 (dummy) & $-0.231(0.059)$ & $-0.225(0.058)$ & $-0.213(0.042)$ & $-0.204(0.043)$ \\
\hline Frailty variance $(\hat{\vartheta})$ & & & $0.443(0.029)$ & $0.394(0.028)$ \\
\hline Observations & 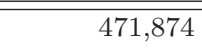 & 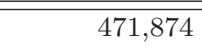 & 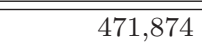 & 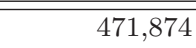 \\
\hline Workers & 101,759 & 101,759 & 101,759 & 101,759 \\
\hline Transitions & 5,714 & 5,714 & 5,714 & 5,714 \\
\hline Log likelihood & 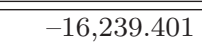 & 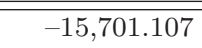 & 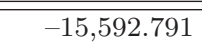 & $\overline{-15,185.256}$ \\
\hline McFadden- $R^{2}$ & 0.159 & 0.187 & 0.192 & 0.213 \\
\hline
\end{tabular}

Notes:

The data set used is version 2 of the LIAB longitudinal model. Robust standard errors (adjusted for intraestablishment correlations in the non-frailty models) are given in parentheses. The dependent variable is a dummy variable taking the value one if the individual changes from an IAB Panel-establishment to non-employment and zero otherwise. Piecewise constant exponential models are fitted with and without shared gamma frailties, where the baseline hazard is a step function in the worker's tenure. Tenure categories are 0-30, 31-60, 61-90, 91-120, 121-150, 151-180, 181-210, 211-240, 241-270, 271-300, 301-330, 31-360, 361-720, 721-1080, 1081-1440, 14411800, 1801-2160, 2161-2520, 2521-2800, 2881-3240, 3241-3600, 3601-5400, 5401-7200, and more than 7200 days of employment, respectively. 
Starting with gender differences, works councils may be more inclined to represent the interests of men than of women for at least two reasons: First, since in Germany the labor force attachment of women and their share in the workforce is traditionally lower than that of men, works councillors who aim to be reelected have a strong incentive to serve men first. This is consistent with empirical findings of a negative correlation between the employment share of women in a plant and the probability of works council existence (see, e.g., Hübler and Jirjahn, 2003; Addison et al., 2003). Second, works councils are still dominated by men. The share of female works council members is substantially lower than women's employment share, and in eight out of nine works councils the chair person is a man (see Niedenhoff, 2002, p. 316).

If works councils do primarily represent the interests of male employees, the coefficients of the works council dummies in the two hazard rate models should be lower in absolute value for women than for men. Table 4 shows that this is indeed the case in every specification. Moreover, works council impact on separations to employment is not statistically significant for women, whereas for men we find the same pattern as in table 2 for the full sample (i.e. works council effects loose significance once wage and profitability variables are included). Concerning separations to non-employment, we find evidence for the works council insurance function in both subgroups, but estimated works council effects are twice as high for men than for women in our preferred specifications with wage and profitability variables. ${ }^{23}$ Taken together, these results suggest that works council existence is indeed more favorable for men than for women (even if we are not able to prove that women's interests are neglected on purpose). ${ }^{24}$

The effects of works council existence on the two separation rates may vary between groups of workers with different tenure. Concerning separations to nonemployment, we would expect that a works council insures more tenured workers more effectively against dismissals as these are arguably the works council's primary clientele (although employment protection of this group is usually higher even in the absence of a works council). As regards the separation rate to employment, improving working conditions via the voice route may show up more pronouncedly

23 One might argue that the lower works council impact for women arises because they are more likely to move (voluntarily) into non-employment. Although it is not very convincing to treat the hazards of separation into unemployment and into unknown destinations as independent, we also estimated the probability of separations into unemployment as a sort of robustness check. These (unreported) estimations showed the same pattern, i.e. the existence of a works council reduces the exits into unemployment more for men than for women.

24 With respect to wages, however, it has been shown that women profit more from the presence of works councils than do men and that works councils reduce the gender wage gap (see Gartner and Stephan, 2004; Heinze and Wolf, 2009; Addison et al., 2009). In addition, Heywood and Jirjahn (2009) report that family-friendly work-practices (which should be more important for female employees) are more likely if a works council exists. 
Table 4: The impact of a works council on the instantaneous separation rate to employment and non-employment by gender

\begin{tabular}{|c|c|c|c|c|c|c|c|}
\hline \multicolumn{8}{|c|}{ Female workers } \\
\hline \multicolumn{4}{|c|}{ Separations to employment } & \multicolumn{4}{|c|}{ Separations to non-employment } \\
\hline \multicolumn{2}{|c|}{$\begin{array}{l}\text { without } \\
\text { establishment- } \\
\text { frailties }\end{array}$} & \multicolumn{2}{|c|}{$\begin{array}{l}\text { with } \\
\text { establishment- } \\
\text { frailties }\end{array}$} & \multicolumn{2}{|c|}{$\begin{array}{l}\text { without } \\
\text { establishment- } \\
\text { frailties }\end{array}$} & \multicolumn{2}{|c|}{$\begin{array}{c}\text { with } \\
\text { establishment- } \\
\text { frailties }\end{array}$} \\
\hline (1) & $(2)$ & (1) & $(2)$ & $(1)$ & $(2)$ & (1) & $(2)$ \\
\hline $\begin{array}{c}-0.091 \\
(0.080)\end{array}$ & $\begin{array}{l}-0.049 \\
(0.083)\end{array}$ & $\begin{array}{c}-0.111 \\
(0.080)\end{array}$ & $\begin{array}{l}-0.049 \\
(0.082)\end{array}$ & $\begin{array}{l}-0.315 \\
(0.097)\end{array}$ & $\begin{array}{l}-0.175 \\
(0.095)\end{array}$ & $\begin{array}{l}-0.351 \\
(0.090)\end{array}$ & $\begin{array}{l}-0.175 \\
(0.091)\end{array}$ \\
\hline \multicolumn{8}{|c|}{ Male workers } \\
\hline \multicolumn{4}{|c|}{ Separations to employment } & \multicolumn{4}{|c|}{ Separations to non-employment } \\
\hline \multicolumn{2}{|c|}{$\begin{array}{l}\text { without } \\
\text { establishment- } \\
\text { frailties }\end{array}$} & \multicolumn{2}{|c|}{$\begin{array}{l}\text { with } \\
\text { establishment- } \\
\text { frailties }\end{array}$} & \multicolumn{2}{|c|}{$\begin{array}{c}\text { without } \\
\text { establishment- } \\
\text { frailties }\end{array}$} & \multicolumn{2}{|c|}{$\begin{array}{c}\text { with } \\
\text { establishment- } \\
\text { frailties }\end{array}$} \\
\hline (1) & $(2)$ & (1) & $(2)$ & (1) & $(2)$ & (1) & $(2)$ \\
\hline $\begin{array}{l}-0.155 \\
(0.066)\end{array}$ & $\begin{array}{c}-0.126 \\
(0.063)\end{array}$ & $\begin{array}{l}-0.147 \\
(0.063)\end{array}$ & $\begin{array}{l}-0.097 \\
(0.063)\end{array}$ & $\begin{array}{l}-0.522 \\
(0.129)\end{array}$ & $\begin{array}{l}-0.350 \\
(0.114)\end{array}$ & $\begin{array}{l}-0.490 \\
(0.074)\end{array}$ & $\begin{array}{l}-0.322 \\
(0.073)\end{array}$ \\
\hline
\end{tabular}

(1) model without, (2) model with log wage and profitability as regressors

Notes:

Reported numbers are the estimated coefficient of the works council dummy in a piecewise constant exponential model for the instantaneous separation rate to employment and non-employment, respectively, like those models from tables 2 and 3. Robust standard errors (adjusted for intra-establishment correlations in the non-frailty models) are given in parentheses.

for less tenured employees. This should hold because more tenured employees, who have acquired more firm-specific human capital, have obviously decided to stay with the firm for a longer time and thus cannot be too discontent with the establishment's working conditions. To investigate these two hypotheses, we added interaction terms of works council existence and five tenure dummies to the hazard models, where tenure categories are given by not more than $0.5,0.5-1,1-2,2-5$ and more than 5 years.

Table 5 reports results that are in line with both conjectures. In all specifications, the negative impact of the works council dummy on the separation rate to nonemployment is more pronounced for workers with higher tenure. More precisely, there is a negative and significant effect only for workers whose tenure is more than one year, where the highest effect is found for workers with more than five years of tenure. For this group the separation rate is decreased by 35.3 percent in the non- 
Table 5: The impact of a works council on the instantaneous separation rate to employment and non-employment by tenure

\begin{tabular}{|c|c|c|c|c|c|c|c|c|}
\hline \multirow[b]{3}{*}{$\begin{array}{l}\text { Workers' } \\
\text { tenure }\end{array}$} & \multicolumn{4}{|c|}{ Separations to employment } & \multicolumn{4}{|c|}{ Separations to non-employment } \\
\hline & \multicolumn{2}{|c|}{$\begin{array}{l}\text { without } \\
\text { establishment- } \\
\text { frailties }\end{array}$} & \multicolumn{2}{|c|}{$\begin{array}{c}\text { with } \\
\text { establishment- } \\
\text { frailties }\end{array}$} & \multicolumn{2}{|c|}{$\begin{array}{c}\text { without } \\
\text { establishment- } \\
\text { frailties }\end{array}$} & \multicolumn{2}{|c|}{$\begin{array}{c}\text { with } \\
\text { establishment- } \\
\text { frailties }\end{array}$} \\
\hline & (1) & $(2)$ & (1) & (2) & (1) & (2) & (1) & (2) \\
\hline$\leqslant 0.5$ years & $\begin{array}{l}-0.478 \\
(0.162)\end{array}$ & $\begin{array}{l}-0.442 \\
(0.161)\end{array}$ & $\begin{array}{l}-0.395 \\
(0.150)\end{array}$ & $\begin{array}{l}-0.329 \\
(0.151)\end{array}$ & $\begin{array}{l}-0.145 \\
(0.186)\end{array}$ & $\begin{array}{c}0.021 \\
(0.177)\end{array}$ & $\begin{array}{l}-0.079 \\
(0.139)\end{array}$ & $\begin{array}{c}0.090 \\
(0.139)\end{array}$ \\
\hline $0.5-1$ years & $\begin{array}{l}-0.447 \\
(0.122)\end{array}$ & $\begin{array}{c}-0.412 \\
(0.121)\end{array}$ & $\begin{array}{l}-0.467 \\
(0.116)\end{array}$ & $\begin{array}{l}-0.394 \\
(0.117)\end{array}$ & $\begin{array}{l}-0.331 \\
(0.162)\end{array}$ & $\begin{array}{l}-0.134 \\
(0.154)\end{array}$ & $\begin{array}{l}-0.137 \\
(0.115)\end{array}$ & $\begin{array}{c}0.078 \\
(0.116)\end{array}$ \\
\hline $1-2$ years & $\begin{array}{l}-0.215 \\
(0.094)\end{array}$ & $\begin{array}{l}-0.177 \\
(0.092)\end{array}$ & $\begin{array}{l}-0.186 \\
(0.079)\end{array}$ & $\begin{array}{l}-0.118 \\
(0.080)\end{array}$ & $\begin{array}{l}-0.513 \\
(0.202)\end{array}$ & $\begin{array}{l}-0.334 \\
(0.186)\end{array}$ & $\begin{array}{l}-0.460 \\
(0.082)\end{array}$ & $\begin{array}{l}-0.245 \\
(0.082)\end{array}$ \\
\hline $2-5$ years & $\begin{array}{c}-0.072 \\
(0.085)\end{array}$ & $\begin{array}{l}-0.039 \\
(0.084)\end{array}$ & $\begin{array}{l}-0.079 \\
(0.067)\end{array}$ & $\begin{array}{l}-0.011 \\
(0.067)\end{array}$ & $\begin{array}{l}-0.435 \\
(0.100)\end{array}$ & $\begin{array}{l}-0.284 \\
(0.096)\end{array}$ & $\begin{array}{l}-0.415 \\
(0.080)\end{array}$ & $\begin{array}{l}-0.225 \\
(0.079)\end{array}$ \\
\hline$>5$ years & $\begin{array}{l}-0.086 \\
(0.065)\end{array}$ & $\begin{array}{l}-0.055 \\
(0.066)\end{array}$ & $\begin{array}{l}-0.114 \\
(0.063)\end{array}$ & $\begin{array}{l}-0.058 \\
(0.063)\end{array}$ & $\begin{array}{c}-0.576 \\
(0.099)\end{array}$ & $\begin{array}{l}-0.436 \\
(0.095)\end{array}$ & $\begin{array}{l}-0.640 \\
(0.076)\end{array}$ & $\begin{array}{l}-0.459 \\
(0.075)\end{array}$ \\
\hline
\end{tabular}

(1) model without, (2) model with log wage and profitability as regressors

Notes:

Reported numbers are the estimated coefficient of the interaction term of the works council dummy and the corresponding tenure dummy in a piecewise constant exponential model for the instantaneous separation rate to employment and non-employment, respectively, like those models from tables 2 and 3 . Robust standard errors (adjusted for intra-establishment correlations in the non-frailty models) are given in parentheses.

frailty and 36.8 percent in the frailty model when wages and profitability are included as regressors. From this we conclude that the insurance effect is more important for tenured workers.

As expected, things are the other way round for separations to employment and the voice effect. For workers with up to one year of tenure, the existence of a works council has a substantial negative and significant impact on the separation rate to employment. In the specification with wages and profitability as regressors, for example, the separation rate to employment in the frailty model is reduced by 28.0 percent for workers with not more than half a year of tenure and by 32.6 percent for those with $0.5-1$ years of tenure. In contrast, the estimated coefficients for workers with more than two years of tenure are still negative, but small and insignificant. What is more, while we found only weak evidence for the voice effect in table 2 , when not allowing for heterogeneity in the impact of a works council across differently tenured workers, there seems to exist a clear voice effect for workers who recently joined the firm. For workers with no more than one year of tenure, the magnitude 
and the statistical significance of works council coefficients are not much reduced when monopoly effects are taken into account by including wages and profitability as additional variables. This again underscores that various groups of workers benefit in different ways from works council existence.

\section{Conclusions}

Using a large linked employer-employee data set for western Germany and methods of competing risk survival analysis, we have investigated the effect of works councils on separations, distinguishing between separations to employment and to nonemployment. The results of our empirical analysis indicate that the existence of a works council is associated with a lower separation rate to employment, in particular for men and for workers with low tenure. While works council monopoly effects show up in all specifications, a clear voice effect is only visible for low tenured workers. Works councils are also found to reduce separations to non-employment, and this impact is more pronounced for men. Insurance effects of works councils only show up for workers with tenure of more than one year.

Our results suggest that looking at aggregate effects only could be misleading. It is important to distinguish between different sorts of separations and between various groups of workers in a plant who seem to benefit in different ways from the existence of a works council. Voice and insurance effects, for example, are only visible for subgroups of workers with different tenure. The fact that works councils, which are still dominated by men, are found to reduce particularly the separation rates of men is an indication that they represent the interests of a specific clientele and try to improve primarily the working conditions and job security of their median voters.

In order to investigate this aspect further, we would need information on the gender composition of works councils which is not available in our data set. Another limitation may be that we could only employ a dummy variable indicating the existence of a works council in a plant but lacked information on the type or behavior of the works council, for instance whether it is cooperative or not (some information of this sort will be available in future waves of the data set). Future research should also try to distinguish between quits and dismissals more clearly than we were able with our data set. Despite these limitations, our analysis indicates that works councils do exhibit monopoly, voice, and insurance effects worth to be investigated further, e.g. by studying the impact of introducing or abolishing a works council. 


\section{References}

Abbring, J. H. and van den Berg, G. J. (2007), 'The unobserved heterogeneity distribution in duration analysis', Biometrika 94(1), 87-99.

Addison, J. T. and Belfield, C. R. (2004), 'Union voice', Journal of Labor Research $25(4), 563-597$.

Addison, J. T., Bellmann, L., and Kölling, A. (2004), 'Works councils and plant closings in Germany', British Journal of Industrial Relations 42(1), 125-148.

Addison, J. T., Bellmann, L., Schnabel, C., and Wagner, J. (2003), 'Works councils old and new: Incidence, coverage and determinants', Schmollers Jahrbuch (Journal of Applied Social Science) 123(3), 339-358.

Addison, J. T., Bellmann, L., Schnabel, C., and Wagner, J. (2004), 'The reform of the German works constitution act: A critical assessment', Industrial Relations 43(2), 392-420.

Addison, J. T., Schnabel, C., and Wagner, J. (2001), 'Works councils in Germany: Their effects on establishment performance', Oxford Economic Papers 53(4), 659-694.

Addison, J. T., Schnabel, C., and Wagner, J. (2004), 'The course of research into the economic consequences of German works councils', British Journal of Industrial Relations 42(2), 255-281.

Addison, J. T. and Teixeira, P. (2006), 'The effects of works councils on employment change', Industrial Relations 45(1), 1-25.

Addison, J. T., Teixeira, P., and Zwick, T. (2009), 'German works councils and the anatomy of wages', Industrial and Labor Relations Review, forthcoming.

Agell, J. (2002), 'On the determinants of labour market institutions: Rent seeking vs. social insurance', German Economic Review 3(2), 107-135. 
Alda, H. (2005), Datenbeschreibung der Version 2.0 des LIAB-Längsschnittmodells, Forschungsdatenzentrum des Instituts für Arbeitsmarkt- und Berufsforschung, Datenreport Nr. 7/2005, Nürnberg.

Alda, H., Bender, S., and Gartner, H. (2005), 'The linked employer-employee dataset created from the IAB establishment panel and the process-produced data of the IAB (LIAB)', Schmollers Jahrbuch (Journal of Applied Social Science Studies) $\mathbf{1 2 5}(2), 327-336$.

Andrews, M. J., Bellmann, L., Schank, T., and Upward, R. (2007), Foreign-owned plants and job security, GEP Research Paper 07/36, Nottingham.

Bartelheimer, P. and Wieck, M. (2005), Arbeitslosigkeit und Unterbeschäftigung, in Soziologisches Forschungsinstitut et al., ed., 'Berichterstattung zur sozioökonomischen Entwicklung in Deutschland - Arbeit und Lebensweisen. Erster Bericht', VS Verlag für Sozialwissenschaften, Wiesbaden, pp. 271-302.

Bender, S., Haas, A., and Klose, C. (2000), 'The IAB employment subsample 1975-95', Schmollers Jahrbuch (Journal of Applied Social Science Studies) 120(4), 649-662.

Boockmann, B. and Steffes, S. (2008), Workers, firms, or institutions: What determines job duration for male employees in Germany?, ZEW Discussion Paper 08-116, Mannheim.

Cameron, A. C. and Trivedi, P. K. (2005), Microeconometrics: Methods and Applications, Cambridge University Press, Cambridge.

Delery, J. E., Gupta, N., Shaw, J. D., and Ganster, M. L. (2000), 'Unionization, compensation, and voice effects on quits and retention', Industrial Relations 39(4), 625-645.

Dilger, A. (2002), Ökonomik betrieblicher Mitbestimmung, Rainer Hampp Verlag, München and Mering. 
Ellguth, P. (2006), Betriebsräte und betriebliche Personalfluktuation, in H. S. Buscher, C. Dreger, and U. Walwei, eds, 'Institutionen und Arbeitsmarkt. Messkonzepte, Wirkungszusammenhänge und internationaler Vergleich', Beiträge zur Arbeitsmarkt- und Berufsforschung Nr. 304, Institut für Arbeitsmarkt- und Berufsforschung, Nürnberg, pp. 189-211.

Freeman, R. B. (1980), 'The exit-voice tradeoff in the labor market: Unionism, job tenure, quits and separations', Quarterly Journal of Economics 94(4), 643-673.

Freeman, R. B. and Medoff, J. L. (1984), What Do Unions Do?, Basic Books, New York.

Frick, B. (1996), 'Co-determination and personnel turnover: The German experience', Labour 10(2), 407-430.

Frick, B. and Möller, I. (2003), 'Mandated works councils and firm performance: Labor productivity and personnel turnover in German establishments', Schmollers Jahrbuch (Journal of Applied Social Science Studies) 123(3), 423454.

Frick, B. and Sadowski, D. (1995), Works councils, unions, and firm performance, in F. Buttler, W. Franz, R. Schettkat and D. Soskice, eds, 'Institutional Frameworks and Labor Market Performance', Routledge, London and New York, pp. 46-81.

Gartner, H. (2005), The imputation of wages above the contribution limit with the German IAB employment sample, Forschungsdatenzentrum des Instituts für Arbeitsmarkt- und Berufsforschung, Methodenreport Nr. 2/2005, Nürnberg.

Gartner, H. and Stephan, G. (2004), How collective contracts and works councils reduce the gender wage gap, Institut für Arbeitsmarkt- und Berufsforschung, IAB Discussion Paper No. 7/2004, Nürnberg. 
Heinze, A. and Wolf, E. (2009), 'The intra-firm gender wage gap: A new view on wage differentials based on linked employer-employee data', Journal of Population Economics, forthcoming.

Heywood, J. S. and Jirjahn, U. (2009), 'Family-friendly practices and worker representation in Germany', Industrial Relations 48(1), 121-145.

Hirsch, B., Schank, T. and Schnabel, C. (2008), Differences in labor supply to monopsonistic firms and the gender pay gap: An empirical analysis using linked employer-employee data from Germany, Princeton University, Industrial Relations Section, Working Paper No. 541, Princeton.

Hübler, O. and Jirjahn, U. (2003), 'Works councils and collective bargaining in Germany: The impact on productivity and wages', Scottish Journal of Political Economy 50(4), 471-491.

Jenkins, S. P. (2005), Survival analysis. Unpublished manuscript, Institute for Social and Economic Research, University of Essex.

Jirjahn, U. (2006), 'Ökonomische Wirkungen der Mitbestimmung in Deutschland: Überblick über den Stand der Forschung und Perspektiven für zukünftige Studien', Sozialer Fortschritt 55(9), 215-226.

Kölling, A. (2000), 'The IAB-establishment panel', Schmollers Jahrbuch (Journal of Applied Social Science Studies) 120(2), 291-300.

Kraft, K. (1986), 'Exit and voice in the labor market: An empirical study of quits', Zeitschrift für die gesamte Staatswissenschaft (Journal of Institutional and Theoretical Economics) 142(4), 697-715.

Kraft, K. (2006), 'On estimating the effect of co-determination on personnel turnover', Schmollers Jahrbuch (Journal of Applied Social Science Studies) 126(2), 287-305. 
Niedenhoff, H.-U. (2002), Mitbestimmung in der Bundesrepublik Deutschland, 13th edn, Deutscher Instituts-Verlag, Köln.

Pfeifer, C. (2007), 'Betriebsräte, Tarifverträge und freiwillige Kündigungen von Arbeitnehmern', WSI-Mitteilungen 60(2), 63-69.

van den Berg, G. J. (2001), Duration Models: Specification, Identification and Multiple Durations, in J.J. Heckmann and E.E. Leamer, eds, 'Handbook of Econometrics', Vol. 5, Elsevier, Amsterdam, pp. 3381-3460. 


\section{Appendix}

Appendix Table: Descriptive statistics; means

\begin{tabular}{|c|c|c|c|c|c|}
\hline & All & Men & Women & $\begin{array}{c}\text { Tenure } \\
\leqslant 1 \\
\text { year }\end{array}$ & $\begin{array}{c}\text { Tenure } \\
>1 \\
\text { year }\end{array}$ \\
\hline Works council (dummy) & 0.841 & 0.843 & 0.836 & 0.758 & 0.844 \\
\hline Log. of daily wage & 4.543 & 4.601 & 4.387 & 4.380 & 4.549 \\
\hline Male (dummy) & 0.729 & 1.000 & 0.000 & 0.750 & 0.729 \\
\hline Non-German (dummy) & 0.066 & 0.069 & 0.056 & 0.090 & 0.065 \\
\hline Tenure (number of years) & 10.423 & 10.488 & 10.247 & 0.730 & 10.504 \\
\hline Age under 21 years (dummy) & 0.003 & 0.002 & 0.004 & 0.019 & 0.002 \\
\hline Age $21-25$ years (dummy) & 0.049 & 0.038 & 0.079 & 0.130 & 0.047 \\
\hline Age $26-30$ years (dummy) & 0.114 & 0.105 & 0.138 & 0.191 & 0.112 \\
\hline Age $31-35$ years (dummy) & 0.177 & 0.184 & 0.160 & 0.218 & 0.177 \\
\hline Age $36-40$ years (dummy) & 0.190 & 0.202 & 0.158 & 0.169 & 0.191 \\
\hline Age $41-45$ years (dummy) & 0.175 & 0.178 & 0.167 & 0.127 & 0.176 \\
\hline Age $46-50$ years (dummy) & 0.160 & 0.158 & 0.164 & 0.095 & 0.161 \\
\hline Age $51-55$ years (dummy) & 0.116 & 0.117 & 0.114 & 0.051 & 0.117 \\
\hline Age $56-58$ years (dummy) & 0.017 & 0.017 & 0.015 & 0.001 & 0.017 \\
\hline No apprenticeship, no Abitur (dummy) & 0.156 & 0.148 & 0.177 & 0.192 & 0.154 \\
\hline Apprenticeship, no Abitur (dummy) & 0.692 & 0.696 & 0.679 & 0.616 & 0.694 \\
\hline No apprenticeship, with Abitur (dummy) & 0.007 & 0.007 & 0.009 & 0.009 & 0.007 \\
\hline Apprenticeship and Abitur (dummy) & 0.047 & 0.039 & 0.068 & 0.057 & 0.047 \\
\hline Technical college degree (dummy) & 0.045 & 0.052 & 0.026 & 0.052 & 0.045 \\
\hline University degree (dummy) & 0.053 & 0.057 & 0.042 & 0.075 & 0.053 \\
\hline Basic manual occupation (dummy) & 0.216 & 0.249 & 0.124 & 0.241 & 0.214 \\
\hline Qualified manual occupation (dummy) & 0.177 & 0.225 & 0.048 & 0.160 & 0.177 \\
\hline Engineers and technicians (dummy) & 0.113 & 0.139 & 0.044 & 0.103 & 0.114 \\
\hline Basic service occupation (dummy) & 0.096 & 0.111 & 0.056 & 0.121 & 0.095 \\
\hline Qualified service occupation (dummy) & 0.017 & 0.008 & 0.042 & 0.016 & 0.017 \\
\hline Semi-professional (dummy) & 0.058 & 0.030 & 0.135 & 0.044 & 0.059 \\
\hline Professional (dummy) & 0.016 & 0.015 & 0.017 & 0.020 & 0.015 \\
\hline Basic business occupation (dummy) & 0.054 & 0.032 & 0.112 & 0.056 & 0.054 \\
\hline Qualified business occupation (dummy) & 0.229 & 0.164 & 0.405 & 0.205 & 0.230 \\
\hline Manager (dummy) & 0.025 & 0.028 & 0.017 & 0.034 & 0.025 \\
\hline Establishment size $\leqslant 20$ employees (dummy) & 0.034 & 0.032 & 0.041 & 0.044 & 0.033 \\
\hline Establishment size 21-100 employees (dummy) & 0.190 & 0.191 & 0.185 & 0.209 & 0.189 \\
\hline Establishment size 101-199 employees (dummy) & 0.212 & 0.211 & 0.216 & 0.233 & 0.212 \\
\hline Establishment size 200-299 employees (dummy) & 0.224 & 0.231 & 0.206 & 0.259 & 0.224 \\
\hline Establishment size $\geqslant 300$ employees (dummy) & 0.339 & 0.335 & 0.352 & 0.255 & 0.342 \\
\hline No coll. agreement (dummy) & 0.161 & 0.156 & 0.175 & 0.209 & 0.159 \\
\hline Coll. agreement at sectoral level ( & 0.719 & 0.723 & 0.710 & 0.659 & 0.721 \\
\hline Coll. agreement at firm level (dummy) & 0.119 & 0.121 & 0.115 & 0.132 & 0.119 \\
\hline Proportion of female workers & 0.344 & 0.275 & 0.531 & 0.336 & 0.345 \\
\hline Proportion of qualified workers & 0.728 & 0.729 & 0.725 & 0.681 & 0.730 \\
\hline New production technology (dummy) & 0.486 & 0.456 & 0.567 & 0.486 & 0.485 \\
\hline Bad economic profitability (dummy) & 0.215 & 0.226 & 0.187 & 0.171 & 0.217 \\
\hline Year 2000 (ref. group ) & 0.375 & 0.373 & 0.380 & 0.892 & 0.342 \\
\hline Year 2001 (dummy) & 0.334 & 0.335 & 0.331 & 0.108 & 0.380 \\
\hline Year 2002 (dummy) & 0.291 & 0.292 & 0.289 & 0.000 & 0.278 \\
\hline Agriculture, hunting, and forestry including fishing (dumm & 0.003 & 0.003 & 0.003 & 0.008 & 0.003 \\
\hline Mining, quarrying, electricity, gas, and water supply (dummy) & 0.026 & 0.031 & 0.013 & 0.037 & 0.026 \\
\hline Manufacturing (dummy) & 0.454 & 0.510 & 0.303 & 0.411 & 0.455 \\
\hline Construction (dummy) & 0.042 & 0.054 & 0.010 & 0.048 & 0.042 \\
\hline Trade and repair (dummy) & 0.088 & 0.084 & 0.098 & 0.099 & 0.088 \\
\hline Transport, storage and communication (dummy) & 0.025 & 0.030 & 0.013 & 0.028 & 0.025 \\
\hline Financial intermediation (dummy) & 0.048 & 0.039 & 0.070 & 0.032 & 0.048 \\
\hline Business activities (dummy) & 0.049 & 0.049 & 0.050 & 0.079 & 0.049 \\
\hline Other activities (dummy) & 0.124 & 0.079 & 0.244 & 0.136 & 0.123 \\
\hline Non-profit organizations and public administration (dummy) & 0.141 & 0.120 & 0.197 & 0.123 & 0.141 \\
\hline Workers & 101,759 & 74,232 & 27,527 & 10,653 & 100,363 \\
\hline
\end{tabular}

Notes:

The sum of workers with not more than one year of tenure and of workers with more than one year of tenure $(111,016)$ is larger than the total number of workers $(101,759)$ since 9,257 workers switch between both categories during the observation period. 